\title{
Habitat suitability modelling for sardine juveniles (Sardina pilchardus) in the Mediterranean Sea
}

\author{
Marianna Giannoulaki ${ }^{1,{ }^{*}}$, Maria M. Pyrounaki ${ }^{1}$, Bernard Liorzou ${ }^{3}$, Iole Leonori ${ }^{4}$, Vasilis D. Valavanis ${ }^{1}$, \\ Konstantinos Tsagarakis ${ }^{1}$, Jean L. Bigot ${ }^{3}$, David Roos ${ }^{4}$, Andrea de Felice ${ }^{4}$, Fabio Campanella ${ }^{4}$, \\ Stylionos Somarakis ${ }^{1}$, Enrico Arneri ${ }^{4}$, Athanassios Machias ${ }^{2}$
}

\footnotetext{
${ }^{1}$ Hellenic Centre for Marine Research, Institute of Marine Biological Resources, PO Box 2214, GR 71003, Iraklion, Greece

${ }^{2}$ Hellenic Centre for Marine Research, Institute of Marine Biological Resources, Agios Kosmas, GR 16610, Athens, Greece

${ }^{3}$ IFREMER, Boulevard Jean Monnet, B.P. 171 34203, Sète Cedex, France

${ }^{4}$ Istituto di Scienze Marine, CNR, Largo Fiera della Pesca, 60125 Ancona, Italy

*: Corresponding author : Marianna Giannoulaki, email address : marianna@her.hcmr.gr
}

\begin{abstract}
:
Identification of potential juvenile grounds of short-lived species such as European sardine (Sardina pilchardus) in relation to the environment is a crucial issue for effective management. In the current work, habitat suitability modelling was applied to acoustic data derived from both the western and eastern part of the Mediterranean Sea. Early summer acoustic data of sardine juveniles were modelled using generalized additive models along with satellite environmental and bathymetry data. Selected models were used to construct maps that exhibit the probability of presence in the study areas, as well as throughout the entire Mediterranean basin, as a measure of habitat adequacy. Areas with high probability of supporting sardine juvenile presence persistently within the study period were identified throughout the Mediterranean Sea. Furthermore, within the study period, a positive relationship was found between suitable habitat extent and the changes in abundance of sardine juveniles in each study area.
\end{abstract}

Keywords : generalized additive models ; habitat suitability modelling ; Mediterranean Sea ; potential juvenile habitat ; sardine juveniles ; small pelagic fish 


\section{INTRODUCTION}

During the last decade, the implementation of fisheries management measures has been related to the reduction of fishing pressure on fish juveniles and their habitats. It is recognised within the latest European Common Fishery Policy that in order to maintain the integrity, structure and functioning of ecosystems, safeguarding of fish nursery areas is necessary. In the Mediterranean, recent stock assessments show that over 50\% of stocks are overexploited (Cardinale et al., 2010). This makes the collection of information on juveniles and spawning grounds for demersal and small pelagic species a necessity for effective management measures.

The European sardine (Sardina pilchardus) is a short-lived, fast growing and highly fecund pelagic fish species. The majority of individuals become mature during their first year of life. Spawning in the Mediterranean takes place during winter with a second peak occurring during March, largely depending on temperature (Ganias et al., 2007). Therefore, spring and summer correspond to periods with high abundance of sardine juveniles. The majority of existing studies addressing the issue of the spatial distribution of sardine in relation to the environment refer mostly to major upwelling areas or the Bay of Biscay in the northeast Atlantic waters (Barange et al., 1999; Bellier et al., 2007; Planque et al., 2007; Barange et al., 2009; Checkley et al., 2009 and references therein). This sort of information is generally lacking for the Mediterranean.

In the Mediterranean, information on sardine distribution grounds mainly derives from standard stock assessment surveys that are regularly held in the European part of the basin. Such surveys in the Gulf of Lions (western part of the basin) and in the North Aegean Sea (eastern part of the basin) are carried out on an annual basis, during 
early summer (Bigot, 2009; Giannoulaki et al., 2009). Existing habitat studies focus mainly on sardine adults (Bellido et al., 2008; Giannoulaki et al., 2007) whereas the identification of juvenile grounds is an issue that is rarely addressed (Tsagarakis et al., 2008). However, juveniles are much more vulnerable to environmental changes compared to adults and are a better index of stock status when it comes to short-lived, small pelagic species like the sardine. Therefore, the main objective of the current work was to model the spatial distribution of sardine juveniles along with environmental parameters on a regional scale. In a subsequent step, the intention was to use this modelled relationship to construct probability maps for the study areas as well as for the entire Mediterranean basin as a measure of habitat adequacy.

For this purpose, habitat suitability modelling that links species location information to environmental data (e.g. Guisan and Zimmermann, 2000; Francis et al., 2005; Planque et al., 2007) was applied. The idea was to select simple, robust but biologically meaningful and effective habitat models (Hilborn and Mangel, 1997) that are based on bathymetry and satellite environmental data. This would allow the application of model results over a wider spatial scale. Satellite environmental data were chosen as they are flexible and dynamic in space and time, allowing estimates on various temporal and spatial scales, operate as proxies or surrogates to causal factors and from which we can infer spatial variations of environmental factors.

Selected models were used to construct maps of sardine nursery grounds that show the probability of sardine juvenile presence in the study areas as well as throughout the entire Mediterranean basin, as a measure of habitat adequacy. This is of special ecological interest for the Mediterranean. The basin, although it is generally considered oligotrophic, presents high heterogeneity in hydrology and large differences of productivity between the western and eastern part of the basin 
(Lejeusne et al., 2010). Moreover, in the face of future climate change, mapping sardine nurseries throughout the basin allows us to identify areas that could be more susceptible to climate warming than others. On the other hand, the temporal persistence of areas indicated to be juvenile grounds within the study period might aid effective management decisions.

Finally, on a local scale within each study area where appropriate data were available, we examined the relationship between the annual change in the spatial extent of sardine potential nursery grounds and the abundance of sardine juveniles, in order to investigate possible density dependent effects that are known to occur in small pelagic fish populations (Barange et al., 2009).

\section{The study areas}

The Gulf of Lions (Fig. 1) is one of the most productive zones in the western Mediterranean Sea owing to a number of hydrographic features like the existence of wide continental shelf, river run-off and strong vertical mixing during winter. Occasional coastal upwelling is generated by local wind systems and complex orographic effects (Millot, 1990; Lloret et al., 2001; Forget and Andre, 2007).

The North Aegean Sea is characterized by high hydrological complexity mostly related to the Black Sea waters (BSW) that enter the Aegean Sea through the Dardanelles strait as a surface current, the Limnos-Imvros stream (LIS) (Zervakis and Georgopoulos, 2002, Fig. 1b). The outflow of BSW enhances local productivity and its advection in the Aegean Sea induces high hydrological and biological complexity (Isari et al., 2006; Somarakis and Nikolioudakis, 2007). This is further enhanced by the presence of a series of large rivers that outflow into semi-closed gulfs (Isari et al., 2006). 
The Adriatic Sea is an elongated basin located in the Central Mediterranean. Its northern section is very shallow, gently sloping, with an average bottom depth of about $35 \mathrm{~m}$ and a large number of rivers discharging into it. The main outflow input derives from the Po River in the northern part, causing large nutrient concentrations along the coast. In contrast, the eastern coastal waters present moderate production. The general circulation is cyclonic with a northwest flow along the eastern coast (East Adriatic Current) and a return southeast flow (West Adriatic Current) along the western coast (Artegiani et al., 1997a, Artegiani et al., 1997b).

\section{MATERIALS AND METHODS}

\section{Acoustic Sampling}

Acoustic data from standard monitoring stock assessment surveys were used to model the presence of sardine juveniles during the summer in the Gulf of Lions, the North Aegean Sea and the south western part of the Adriatic Sea. Acoustic sampling was performed by means of scientific split-beam echosounders (Simrad EK500 and Biosonic DT-X depending on the survey) operating at $38 \mathrm{kHz}$ and calibrated following standard techniques (Foote et al., 1987). Data were recorded at a constant speed of 8-10 $\mathrm{nmi} \mathrm{h}{ }^{-1}$. Minimum sampling depth varied between 10 to $20 \mathrm{~m}$ depending on the area. The size of the Elementary Distance Sampling Unit (EDSU) was one nautical mile (nmi, $1.852 \mathrm{~km}$ ). Midwater pelagic trawl sampling was used to identify sardine juvenile echo traces. Sardine specimens smaller than $125 \mathrm{~mm}$ were considered as juveniles as this approximates the length of first maturity for the European sardine in the Mediterranean (Somarakis et al., 2006; Ganias et al., 2007). Sardine juvenile echo discrimination was based on the characteristic echogram shape 
of the schools and the catch composition of pelagic trawling that was held in the study area (Simmonds and MacLennan, 2005). Acoustic data analysis was done with Myriax Echoview software in the N. Aegean Sea and the Adriatic, whereas Movies+ software was used in the Gulf of Lions. Further details on acoustic sampling per study area are described below.

In the Gulf of Lions, data were collected on board the R/V “L'EUROPE” during July 2003-2008 (Fig. 1a). Acoustic surveys were carried out along predetermined parallel transects, perpendicular to bathymetry with $12 \mathrm{nmi}$ inter transect distance. Records of each EDSU were combined following the method outlined in Petitgas et al. (2003) in order to allocate fractions of the total energy recorded (NASC: nautical area scattering coefficient) in term of biomass to the various species captured in the trawl. For each EDSU, this biomass was reallocated in terms of number of individuals per size and age according to the mean weight observed in the reference trawl. In the N. Aegean Sea, acoustic data were collected on board the R/V “PHILIA” during June 2004-2006 and 2008 along predetermined parallel transects with $10 \mathrm{nmi}$ inter-transect distance in open areas, whereas zigzag transects were sampled inside gulfs (Fig. 1). Details of the surveys, sampling methodology and data collected are described elsewhere (Giannoulaki et al., 2008). Moreover, acoustic data were collected during July 2007 and 2008 in a lesser part of North Aegean Sea, within the framework of acoustic surveys targeted for sardine juveniles (Fig. 1b). Sardine juvenile abundance and distribution based on these acoustic estimates shows a large degree of interannual variability in both the Gulf of Lions and N. Aegean Sea study areas (Figs. 2, 3). However, the highest abundances and main concentrations were located in the inner, north western part of the Gulf of Lions and the north part of the Thracian Sea. 
Complementary data from one acoustic survey, held in the southwest part of the Adriatic Sea, were used to evaluate the estimated models. Data were collected on board the R/V "DALLAPORTA” during July 2008 along predetermined parallel transects perpendicular to the coastline with $10 \mathrm{nmi}$ inter-transect distance and $8 \mathrm{nmi}$ where the continental shelf is narrow (Fig. 1d; Leonori et al., 2009; Leonori et al., 2010).

\section{Environmental data}

Satellite environmental data as well as bathymetry data were used for modelling the habitat of sardine juveniles in respect to environmental conditions. The Mediterranean Sea is an area well monitored in terms of monthly satellite imagery (summarised in Table 1). Specifically, the sea surface temperature distribution (SST in ${ }^{\circ} \mathrm{C}$ ), the sea surface chlorophyll concentration (CHLA in $\mathrm{mg} \mathrm{m}^{-3}$ ), the Photosynthetically Active Radiation (PAR in Einstein $\mathrm{m}^{-2}$ day $^{-1}, 1$ Einstein (Ein) $=1$ mole of photons), the sea surface salinity distribution (SSS in psu based on the BCC GODAS model, Behringer and Xue, 2004) and the sea level anomaly (SLA in cm) were downloaded from respective databases (see Table 1) and used. These environmental variables are considered important either as a direct influence on the distribution of sardine juveniles (e.g. SST, CHLA) or as a proxy for causal factors (Bellido et al., 2001). For example, SLA varies with ocean processes such as gyres, meanders and eddies (Larnicol et al., 2002; Pujol and Larnicol, 2005) which enhance productivity and often function as physical barriers differentiating the distribution of species or species life stages. Similarly, satellite measured SeawiFs PAR is the photosynthetically available radiant energy (integrated over the spectral range 400-700 $\mathrm{nm}$ ) reaching the sea surface over a 24 hour period (Frouin et al. 2003). It is indicative of the solar energy 
available for photosynthesis, controlling the growth of phytoplankton thus critical also for fisheries and carbon dynamics. It is often used to determine the euphotic depth in the ocean taking into account light attenuation and absorption (Kirk 1996). Bathymetry, as an indirect factor, was derived from a blending of depth soundings collected from ships with detailed gravity anomaly information obtained from the Geosat and ERS-1 satellite altimetry missions (Smith and Sandwell, 1997). Such topographic variables have the potential to summarize important surrogate predictor variables that are not captured by the available satellite variables. All monthlyaveraged satellite images from daily measurements were processed as regular grids under a GIS (Geographic Information Systems) environment using ArcInfo GRID software (ESRI, 1994). Thus, mean environmental monthly values for June and July of each respective year were assigned to each survey point based on a spatial resolution of $1.5 \mathrm{~km}$ (Valavanis et al., 2008).

\section{Data analysis}

\section{Model estimation}

Generalized Additive Models (GAMs) were applied in order to define the set of the environmental factors that describe sardine juvenile distribution grounds in the $\mathrm{N}$. Aegean Sea during June and in the Gulf of Lions during July. The main advantage of GAMs over traditional regression methods is their capability to model non-linearities using non-parametric smoothers (Hastie and Tibshirani, 1990; Wood, 2006). The selection of the GAMs smoothing predictors followed the method proposed by Wood and Augustin (2002), using the 'MGCV' library in the R statistical software (R Development Core Team, 2008). Each model fit was analysed in regard to the level of deviance explained (0-100\%; the higher the percentage, the more deviance 
explained), the Akaike's Information Criterion (AIC, the lower the better) and the confidence region for the fit (which should not include zero throughout the range of the predictor). The degree of smoothing was chosen based on the observed data and the Generalized Cross Validation (GCV) method suggested by Woods (2006) and incorporated in the 'MGCV' library. The GCV method is known to over-fit, therefore the amount that the effective degree of freedom of each model counts in the GCV score was increased by a factor $\gamma=1.4$ (Katsanevakis et al., 2009).

Autocorrelation was evident in the spatial structure of acoustic data in both areas. Spatial autocorrelation is known to inflate the perceived ability of models to make realistic predictions favouring autocorrelated variables (Segurado et al., 2006), although GAMs are not that much influenced by the effect of autocorrelation compared to other methodologies like GLMs (Segurado et al., 2006). However, in order to avoid this effect, we adjusted to Type I error rate by setting the accepted significance level for each term at the more conservative value of $1 \%$, rather than the usual 5\% (Fortin and Dale, 2005). Removing autocorrelation by means of subsampling, taking into account the observed autocorrelation range as a "distance to independence”, was not considered an option. This would be very wasteful of data (Fortin and Dale, 2005) and may result in a non-applicable model for mapping probabilities of habitat adequacy.

Models were constructed based on a) pooled data from both the Gulf of Lions and N. Aegean Sea including the factorial variable of the monthly effect and based on b) data from each area and month, separately (i.e. the Gulf of Lions in July and the N. Aegean Sea in June). For each case, a final model was built by testing all variables that were considered biologically meaningful, starting from a simple initial model with one explanatory variable. The best model was selected based on the 
minimization of the AIC score. This approach reduces the collinearity problem in the independent variables (Sacau et al., 2005). Specifically, as response variable (y), we used the presence/absence of sardine juveniles. As independent variables (x covariates), we used the cube root of the bottom depth (to achieve a uniform distribution of bottom depth), the natural logarithm of CHLA (to achieve a uniform distribution of CHLA), SST, SSS, SLA and PAR. Original values of bottom depth and CHLA were highly variable, thus transformation was necessary in order to achieve uniform distributions for GAM application (Hastie and Tibshirani, 1990).

The binomial error distribution with the logit link function was used and the natural cubic spline smoother (Hastie and Tibshirani, 1990) was applied for independent variables smoothing and GAM fitting. Following the selection of the main effects of the model, all first order interactions of the main effects were tested (Wood, 2006). Validation graphs (e.g. residuals versus fitted values, QQ-plots and residuals versus the original explanatory variables) were plotted in order to detect the existence of any pattern and possible model misspecification. Residuals were also checked for autocorrelation. The output of the final selected GAMs is presented as plots of the best-fitting smooths. Interaction effects are shown as a perspective plot without error bounds.

\section{Model validation}

In a subsequent step, each final model was tested and evaluated for its predictive performance. For this purpose, we estimated the Receiver Operating Characteristic curve (ROC) (Hanley and McNeil, 1982; Guisan and Zimmerman, 2000) and the AUC metric, the area under the ROC. AUC is a threshold-independent metric, widely used in the species' distribution modelling literature (Franklin, 2009; Weber and 
McClatchie, 2010). Moreover, sensitivity (i.e. the proportion of observed positives that are correctly predicted) and specificity values (i.e. the proportion of observed negatives that are correctly predicted) were also used for model evaluation (Lobo et al., 2008). They were measured in relation to two threshold criteria: a) the maximization of the specificity-sensitivity sum (MDT) and b) the prevalence values (Jimenez-Valverde and Lobo, 2007; Lobo et al., 2008).

All metrics were also estimated for areas and periods not included in model selection: a) both the North and South Evoikos Gulf (Aegean Sea) in June 2004 and June 2008, b) the Gulf of Lions in July 2006 and 2007 and c) the western part of South Adriatic Sea in July 2008. New datasets of mean monthly satellite values, estimated for each sampled coordinate, were used for this purpose. A specific probability of habitat adequacy for sardine juveniles was estimated for each geographic coordinate. All metrics estimation was performed using the “Presence/Absence” library of R statistical language.

\section{Mapping}

Based on validation results, the selected single month models were applied in a predictive mode to provide probability estimates and habitat adequacy over a grid of mean monthly satellite values at a GIS resolution of $4 \mathrm{~km}$, the best resolution available for satellite environmental data at a large scale, covering the entire Mediterranean basin. Subsequently, annual habitat suitability maps were constructed for June and July 2004 to 2008. GIS techniques were used to estimate the mean of these annual maps, summarising the mean average probability estimates at each grid point. Similarly, the variability map, representing the inter-annual variability in 
nursery grounds, was also produced estimating the standard deviation of the annual maps from 2004 to 2008.

Additionally, maps indicating areas that persistently represented juvenile grounds within the study period were drawn. For this purpose, for each grid cell (at a spatial resolution of $4 \mathrm{~km}$ ) in the entire Mediterranean Sea, we calculated an Index of Persistence $\left(I_{i}\right)$, measuring the relative persistence of the cell $i$ as an annual sardine nursery (Fiorentino et al., 2003; Colloca et al., 2009). Let $\delta_{i j}=1$ if the grid cell $i$ is included in a sardine nursery in year $j$, and $\delta_{i j}=0$ if the grid cell is not included. We computed $I_{i}$ as follows:

$$
I_{i}=\frac{1}{n} \sum_{k=1}^{n} \delta_{i j}
$$

where $n$ is the number of surveys considered. $I_{i}$ ranges between 0 (cell $i$ never included in an annual sardine nursery area) and 1 (cell $i$ always included in an annual sardine nursery area) for each cell in the study area.

Preferential and occasional nursery grounds were defined following Bellier et al. (2007) based on average, variability and persistence maps. Based on Bellier et al. (2007) a habitat allocation map was created indicating: (a) recurrent juvenile sites areas with high mean, low standard deviation values and high persistence index, (b) occasional juvenile sites - areas with high mean and high standard deviation values (sardine juveniles are present in some years but not in others in these areas) and (c) rare juvenile sites - areas with low mean and low standard deviation values (sardine juveniles are rarely present in these areas). The Surfer v8.0 of the Golden Software Inc. software was used for mapping. 
Within the current work we also examined the relationship between the change in the extent of "hot spot areas" (i.e., potential habitat area with high probability of sardine juveniles presence $>0.75$, defined as A075) and the change in abundance of sardine juveniles, in each study area for the study period. For this purpose in each study area (i.e., Gulf of Lions, Adriatic Sea and North Aegean Sea, Fig. 1) we calculated the number of grid cells presenting high probability of sardine juvenile presence (i.e., > 0.75). The abundance of sardine juveniles (i.e. annual estimates of the number of age 0 fish) was derived either from age structure stock assessment models (Cardinale et al., 2009: N. Aegean and Adriatic Seas) and from acoustic estimates of sardine juveniles in the case of Gulf of Lions, when no stock assessment model was available. Abundance estimates and the extent of "hot spot areas" (i.e., extent of A075) were both standardized and expressed, as \% difference from the mean values per region in order to assure compatibility between areas.

\section{RESULTS}

\section{Habitat modelling}

Pooled Model: Gulf of Lions and North Aegean Sea

GAMs based on the pooled data from both areas are presented on Table 2. Plots of the best fitting smooths showed a higher probability of finding sardine juveniles present in SST values of $21.5-24.5^{\circ} \mathrm{C}$, CHLA values of $0.345-2.718 \mathrm{mg} \mathrm{m}^{-3}$ (Fig. 4). The interaction plot between Depth and SLA also indicated a higher probability of finding sardine juveniles present in shallow waters (less than $65 \mathrm{~m}$ ) when co-existing with SLA values of between 0 and $-5 \mathrm{~cm}$ (Fig. 4). 


\section{Gulf of Lions, July}

Final selected GAM for July included as main effects: SLA, CHLA (log transformed) and the interactive effect of Depth (cubic root transformed) and SST (Table 2). Plots indicate a higher probability of finding sardine juveniles present in the highest available SLA values of $-1 \mathrm{~cm}$ to $3 \mathrm{~cm}$ and CHLA values of $0.345-2.718 \mathrm{mg} \mathrm{m}^{-3}$ (Fig. 4). The interaction plot between SST and Depth indicates a higher probability of finding sardine juveniles present in the highest available values of SST $\left(20-26{ }^{\circ} \mathrm{C}\right)$ when co-existing with shallower waters (less than $60 \mathrm{~m}$ ) (Fig. 4).

\section{North Aegean Sea, June}

The final selected GAM included as main effects: SLA, CHLA (log transformed) as well as the interactive effect of Depth (cubic root transformed) and PAR (Table 2). Plots indicate a higher probability of finding sardine juveniles present in SLA values of $-6 \mathrm{~cm}$ to $0 \mathrm{~cm}$ and CHLA values of $0.47-1 \mathrm{mg} \mathrm{m}^{-3}$. The interaction plot between Depth and PAR indicates a higher probability of finding sardine juveniles present in shallow waters (less than $65 \mathrm{~m}$ ) when co-existing with PAR values of 48 to 56 Ein $\mathrm{m}^{-2}$ $\operatorname{day}^{-1}$ (Fig. 4).

In all cases, inspection of the residual plots versus fitted values and against the original explanatory variables indicated no pattern and no apparent trend. Moreover, residuals were checked for spatial autocorrelation by means of geostatistics (Petitgas, 2003). Results either indicate no signs of spatial autocorrelation (i.e. pure random component) or very low levels of spatial autocorrelation (> 86\% random component).

\section{Models validation}


AUC generally showed good discrimination ability for all models since it exceeded on average 0.73 for the cases that were not included in model selection (Table 3). The lowest prediction ability was observed for areas which presented a low percentage of sardine juvenile presence and very patchy spatial distribution of fish. Estimated specificity and sensitivity values based on MDT and prevalence values also indicated good discrimination ability for all models. Specificity values were generally higher than sensitivity ones, ranging from 0.77 to 0.96 thus indicating low omission error for all models (Table 3). Since higher sensitivity values were estimated for the single month models, these models were selected for mapping the estimated probabilities of habitat adequacy.

\section{Habitat suitability maps}

Habitat suitability maps for the study regions generally revealed an agreement between potential nurseries and the observed distribution of sardine juveniles (Figs 2, 3 and 5, 6). The average, persistence and habitat allocation maps for the Mediterranean within the study period (Figs 7 to 8) identified certain areas that were consistently associated with high probability of sardine juvenile presence. In the Western Mediterranean, these areas were located in the Adriatic Sea, the Sicily Channel, the Tyrrhenian Sea, the Gulf of Lions, Catalan and Alboran Seas (Figs 1, 7, 8). Specifically, areas were indicated at the inner coastal waters of the Gulf of Lions, the northern part of the Adriatic Sea, the coastal waters of the western and eastern Adriatic, the gulfs and coastal waters of the N. Aegean Sea. Along the North Africa coast, suitable areas were indicated in the coastal waters of Morocco, Algeria, Tunisia and Libya (Figs 1, 7, 8). In the Eastern Mediterranean, suitable areas were revealed in 
the Turkish coastal waters of the Aegean Sea and along the Egyptian coastline, mainly off the Nile River Delta.

\section{Juvenile abundance versus potential habitat}

A significant positive relationship between the increase in juveniles abundance (i.e., standardized abundance of sardine juveniles) and the increase in habitat extent of "hot spot areas” (i.e., standardized values of A075) was shown (Fig. 9).

\section{DISCUSSION}

Our objective was to identify and map the juvenile grounds of the European sardine in the Mediterranean Sea during summer based on environmental associations. Data from the western (Gulf of Lions) and the eastern part (N. Aegean Sea) of the basin were used for this purpose.

In the study areas, the visual inspection of habitat adequacy maps indicated temporal and spatial variability in terms of suitable sites. Most persistent suitable locations were indicated in the inner, north western part of the Gulf of Lions as well as in the inner parts of the gulfs of the N. Aegean Sea, where shallow, warm and productive waters exist (Figs 5, 6). In the northwestern part of the Gulf of Lions, the presence of two large rivers, the Rhone and the Muga Rivers (Fig. 1), together with an existing upwelling along the coast (Forget and Andre, 2007) results in a local increase of productivity.

In the N. Aegean Sea, the more consistent nursery locations were identified at the coastal areas of the gulfs (i.e., Thermaikos Gulf, Strymonikos Gulf and North Evoikos Gulf) and the inner part of Thracian Sea-these areas are also under strong river influence. Also consistent was the area between the islands, subjected to the inflow of 
the Limnos-Imvros Stream (LIS) that carries nutrient rich Black Sea Water into Thracian Sea (Figs. 1, 6). This further enhances productivity through the generation of gyres and fronts (Zervakis and Georgopoulos, 2002; Somarakis et al., 2002). The indicated areas generally agree with the results of a preliminary study on sardine nurseries in Aegean Sea based on trawl catches (Tsagarakis et al., 2008). These findings also agree with the general argument that pelagic fish nurseries are located in areas of favourable food concentrations where oceanographic factors combine favourably within an optimal environmental window (Cury and Roy, 1989; Guisande et al., 2004; Fréon et al., 2005).

Towards a larger scale perspective, selected models were used to construct annual maps indicating the probability of habitat adequacy for sardine juvenile presence throughout the entire Mediterranean basin. The temporal variability of suitable nursery areas was addressed through the estimation of the mean and the variability map for June and July within the study period. Locations presenting high variability as sardine nurseries were the coastal waters of the North Alboran Sea, the Sicily Strait, the western part of the Italian Peninsula (i.e. the Ligurian and the Tyrrhenian Sea and the area around the island of Sardinia), the Cretan Shelf in Greek seas and areas along the coastline of the Levantine (Figs 1, 7, 8). These areas seem to represent suitable positions for sardine juveniles occasionally, largely depending on the annual variability of environmental conditions.

On the other hand, certain locations were quite persistent. In the north part of the basin, besides the study regions, the most invariable nursery areas were located in the coastal waters of the north western part of the Adriatic and around the coastal waters of the mid-Dalmatian islands in the eastern part (Figs. 1, 7, 8). These areas coincide with known sardine distribution grounds in the Adriatic based on acoustic surveys 
(Ticina et al., 2005; Leonori et al., 2007a, b) as well as fishery information. The bianchetto (fry) fishery is an old established fishery, targeting anchovy and sardine juveniles in the south western part of the Adriatic (Morello \& Arneri, 2009 and references therein). In Spanish waters, persistent nursery areas are located in the Catalan Sea as well as near the mouth of the Ebro River (Figs. 1, 7, 8). These areas coincide with known distribution grounds of sardine juveniles (Giraldez et al., 2005; Alemany et al., 2006). Similarly, in the south part of the basin along the North African coast where information on small pelagic nursery grounds is generally lacking, persistent areas are indicated in the coastal waters of Morocco and Algeria, the gulf of Gabes in Tunisia and the Nile Delta area (Figs. 1, 7, 8). These areas match the distribution grounds of sardine, as landings information from local fisheries confirm (El-Haweet, 2001; Ben Abdallah and Gaamour 2005; Ramzi et al., 2006). Differences in the persistent/recurrent locations between June and July were mainly identified in the Western Mediterranean, the Strait of Sicily as well as the Levantine. In the Western Mediterranean and the Strait of Sicily, suitable areas were more extended in July compared to June, whereas the opposite was observed in the Levantine (Figs. 1, 7, 8).

Areas indicated as potential juvenile grounds seem to largely match sardine adult grounds during summer (Tugores et al., 2010), although juvenile grounds appear less extended and more persistent in terms of locations. This is more clearly evident when it comes to the "hot spot" areas, i.e., areas representing more than $75 \%$ probability of suitable conditions. Spatial overlap is observed also between juvenile grounds during summer compared to sardine spawning grounds during December (Tugores et al., 2010). 
Additionally, the visual inspection of sardine and anchovy juvenile grounds (Giannoulaki et al., 2010) also shows a large degree of overlap. This most likely reflects the peculiarities of the Mediterranean, where suitable areas favouring the growth of juveniles, the feeding of adults and spawning processes, tend to be localised. They are mostly associated with the existence of point sources of nutrients that enhance productivity locally like river runoffs or local upwelling. The existence of such limited, suitable areas along with complex oceanographic and topographic characteristics (i.e. irregularities in the coastline and the bathymetry) are likely to prevent long migrations for sardine between spawning, feeding and juvenile grounds.

Current work shows that in the Mediterranean, similar to large upwelling ecosystems and the Northeast Atlantic, the juvenile grounds of sardine are mainly situated in inshore, coastal waters (Barange et al., 1999; Checkley et al., 2009 and references therein). However, in the high productivity ecosystems, extended migrations of juveniles, feeding and spawning adults are observed between offshore and inshore waters (Checkley et al., 2009 and references therein). This is not the case in the Mediterranean where habitat maps indicate only small scale movements between spawning, juvenile and adult grounds, are always limited to up to $100 \mathrm{~m}$ depth (current findings, Tugores et al., 2010).

Our data for the N. Aegean Sea, the Adriatic Sea and the Gulf of Lions supported the existence of density dependent effects in the populations of sardine juveniles. An increase in the spatial extent of suitable areas was associated with an increase in the abundance of sardine juveniles. Additional years and data availability from more areas are required in order to further examine this relationship. However assessment reports from different parts of the Mediterranean further support this relationship between the extent of sardine distribution grounds and the annual variation of species 
abundance (Bellido et al., 2008; Bigot 2009; Giannoulaki et al., 2009; Leonori et al., 2009, 2010). In the Gulf of Lions, acoustic abundance estimates were highest in 2005, followed by a sharp decrease in 2006 up to 2010 (Bigot and Roos, 2010). In the N. Aegean Sea the highest abundance of sardine was found in 2003, followed by a sharp decrease in 2004 (Giannoulaki et al., 2009). In both areas the stock fluctuations coincided with an expansion of the distribution area in years of high abundance (Bigot and Roos, 2010; Giannoulaki et al., 2008; 2009).

In the western Adriatic Sea, sardine distribution grounds were limited in the north part of the basin when population levels were low in 2005, expanding towards the central and the south part of the basin when abundance was higher in 2007 and 2008 (Leonori et al., 2009, 2010). Moreover, in the Spanish waters the high abundance of sardine adults in 2003 to 2005 was followed by a sharp decrease in 2006 up to 2008, a period presenting pronounced contraction of the distribution area (Bellido et al., 2008; Cardinale et al., 2010)

In various upwelling areas, such as South Africa, Japan, California and Peru, the sardine is known to present density dependent effects with the distribution area increasing following an increase in population size (Barange et al., 1999; 2009). Yearto-year variations in the year-class strength of pelagic fishes in upwelling areas are known to be governed by upwelling intensity, whereas density-dependent processes are particularly likely to come into play after favourable environmental conditions have promoted the high year-class strength (Cole and McGlade, 1998). A well established relationship between habitat extent and fish abundance in the Mediterranean could be used to propose a spatial ecosystem indicator that could flag situations where contraction of the potential suitable habitat implies a subsequent decrease in the population. 
Our approach could be a simple way to compare habitat suitability for different species and visualise any possible spatial shifts under the effect of climate warming. These sort of spatial shifts are reflected in the shrinkage and the expansion of suitable areas for species. Habitat modelling results like the work presented here can provide essential information in order to identify priority areas for the management of sardine stocks in the Mediterranean. Large-scale conservation planning requires the identification of priority areas or areas of particular concern such as fish nursery grounds. Most Mediterranean fish stocks are being reported as fully exploited or overexploited (Cardinale et al., 2010), which indicates the need for large-scale fisheries management. The selection of priority areas for protecting juveniles and maintaining good population status can increase the effectiveness of large-scale fisheries management. At the same time, incorporating such habitat suitability maps into spatial dynamic models like Ecospace (Pauly et al., 2000) can result into an effective, highly dynamic management tool.

\section{Acknowledgements}

This study was supported and financed by the Commission of the European Union through the Project "SARDONE: Improving assessment and management of small pelagic species in the Mediterranean'” (FP6 - 44294). We also want to thank the captain and the crew of the RV "PHILIA", RV "L EUROPE" and RV "DALLAPORTA" as well as all the scientists on board for their assistance during the surveys. We also thank Dr. Alberto Santojanni for the provision of the sardine juveniles abundance based on results of assessment model as well as Beatrice Roel and Pierre Fréon for their constructive comments during the project. 


\section{REFERENCES}

Alemany, F., Alvarez, I., Garcia, A., Cortes, D., Ramirez, T., Quintanilla, J., lvarez, F.A., and Rodriguez, J.M. (2006) Postflexion larvae and juvenile daily growth patterns of the Alboran Sea sardine (Sardina pilchardus Walb.): influence of wind. Sci. Mar. 70: 93-104.

Artegiani, A., Bregant, D., Paschini, E., Pinardi, N., Raicich, F., and Russo A. (1997a) The Adriatic Sea general circulation. Part I. Air-sea interactions and water mass structure. J. Phys. Oceanogr. 27: 1492- 1514.

Artegiani, A., Bregant, D., Paschini, E., Pinardi, N., Raicich, F., and Russo, A. (1997b) The Adriatic Sea general circulation. Part II: Baroclinic Circulation Structure. J. Phys. Oceanogr. 27: 1515- 1532.

Barange, M., Hampton, I., and Roel, B.A. (1999) Trends in the abundance and distribution of anchovy and sardine on the South African continental shelf in the 1990s. S. Afr. J. mar. Sci. 21: 367-391.

Barange, M., Coetzee, J., Takasuka, A., Hill, K., Gutierrez, M., Oozeki, Y., Carl van der Lingen, C., and Agostini, V. (2009) Habitat expansion and contraction in anchovy and sardine populations. Prog. Oceanogr. 83: 251-260.

Behringer, D.W., and Xue, Y. (2004) Evaluation of the global ocean data assimilation system at NCEP: The Pacific Ocean. Eighth Symposium on Integrated Observing and Assimilation Systems for Atmosphere, Oceans, and Land Surface. American Meteorological Society 84th Annual Meeting Proceedings, Washington State Convention and Trade Center, Washington: Seattle, pp. 11-15.

Bellido, J.M., Pierce, G., and Wang, J. (2001) Modelling intra-annual variation in abundance of squid Loligo forbesi in Scottish waters using generalised additive models. Fish. Res. 52: 23-39. 
Bellido, J.M., Brown, A.M., Valavanis, V.D., Giráldez, A., Pierce, G.J., Iglesias, M., and Palialexis, A. (2008) Identifying Essential Fish Habitat for small pelagic species in Spanish Mediterranean waters. Hydrobiologia 612: 171-184.

Bellier, E., Planque, B., and Petitgas, P. (2007) Historical fluctuations of spawning area of anchovy (Engraulis encrasicolus) and sardine (Sardina pilchardus) in the Bay of Biscay from 1967 to 2004. Fish. Oceanogr. 16(suppl. 1): 1-15.

Ben Abdallah, L., and Gaamour, A. (2005) Répartition geographique et estimation de la biomasse des petits pélagiques des cotes tunisiennes. MedSudMed Tec. Doc. 5: 28-38.

Bigot, J.L. (2009) Stock Assessment form of Sardina pilchardus in the Gulf of Lions (GSA07). Working paper, GFCM, SCSA, Working Group on the Small Pelagic. General fisheries commission for the Mediterranean scientific advisory committee, Sub-Committee for Stock Assessment, Working Group on Small Pelagic Species, Ancona, 25-30 October 2009.

Bigot, J.L. and Roos D. (2010) Stock Assessment form of Sardina pilchardus in the Gulf of Lions (GSA07). Working paper, GFCM, SCSA, Working Group on the Small Pelagic. General fisheries commission for the Mediterranean scientific advisory committee, Sub-Committee for Stock Assessment, Working Group on Small Pelagic Species, Mazzara del Vallo, (Sicily), 1-6 November 2010.

Cardinale, M., Cheilari, A., and Ratz, H.J. (2009) Report of the SGMED-09-02 Working Group on the Mediterranean Part I. Scientific, Technical and Economic Committee for Fisheries (STECF), 8-10 June 2009, Villasimius, Sardinia, Italy.

Cardinale, M., Cheilari, A., and Ratz, H.J. (2010) Report of the SGMED-09-02 Working Group on the Mediterranean Part I. Scientific, Technical and Economic Committee for Fisheries (STECF), 4-8 June 2010, Iraklion, Crete, Greece. 
Checkley, D.M., Ayon, P., Baumgartner, T.R., Bernal, M., Coetzee, J.C., Emmett, R., Guevara-Carrasco, R., Hutchings, L., Ibaibarriaga, L., Nakata, H., Oozeki, Y., Planque, B., Schweigert, J., Stratoudakis Y., and van der Lingen C.D. (2009) Habitats. In: Climate Change and Small Pelagic Fish. A. Checkley, J. Alheit, Y. Oozeki, and C. Roy (eds) New York: Cambridge University Press, 372 pp.

Cole, J., and McGlade, J. (1998) Clupeid population variability, the environment and satellite imagery in coastal upwelling systems. Rev. Fish. Biol. Fish. 8: 445-471.

Colloca, F., Bartolino, V., Lasinio, J.J., Maiorano, L., Sartor, P., and Ardizzone, G. (2009) Identifying fish nurseries using density and persistence measures. Mar. Ecol. Progr. Ser. 381: 287-296.

Cury, P., and Roy, C. (1989) Optimal environmental window and pelagic fish recruitment success in upwelling areas. Can. J. Fish. Aquat. Sci. 46: 670-680.

El Haweet, A., (2001) Catch composition and management of daytime purse seine fishery on the Southern Mediterranean Sea Coast, Abu Qir Bay, Egypt. Medit. Mar. Sci. 2(suppl. 2): 119-126.

ESRI (1994) ARC Macro Language. Environmental Systems Research Institute Inc, USA: Redlands, CA, pp. 3-37.

Fiorentino, F., Garofalo, G, De Santi, A., Bono, G., Giusto, G.B., and Norrito, G. (2003) Spatio-temporal distribution of recruits (0 group) of Merluccius merluccius and Phycis blennoides (Pisces, Gadiformes) in the Strait of Sicily (Central Mediterranean). Hydrobiologia 503: 223-236.

Foote, K.G., Knudsen, H.P., Vestenes, G., Maclennan, D.N. and Simmonds, E.J. (1987) Calibration of acoustic instruments for fish density enstimation. A pratical guide. ICES Coop. Res. Rep., 144, 57 pp. 
Forget, P., and André, G. (2007) Can satellite-derived chlorophyll imagery be used to trace surface dynamics in coastal zone? A case study in the northwestern Mediterranean Sea. Sensors 7: 884-904.

Fortin, M.J., and Dale, M. (2005) Spatial analysis: A guide for ecologists. Cambridge University Press.

Francis, M.P., Morrison, M.A., Leathwick, J., Walsh, C., and Middleton, C. (2005) Predictive models of small fish presence and abundance in northern New Zealand harbours. Est. Coast. Sh. Sci. 64: 419-435.

Franklin, J. (2009) Mapping Species Distributions. Spatial Inference and Prediction. New York: Cambridge University Press, 320pp.

Fréon, P., Drapeau, L., David, J.H.M., Fernandez Moreno, A., Leslie, R.W., Oosthuizen, W.H., Shannon, L.J., and van der Lingen, C.D. (2005) Spatialized ecosystem indicators in the southern Benguela. ICES J. Mar. Sci. 62: 459-468.

Frouin, R., Franz, B.A., Werdell, P.J., 2003. The SeaWiFS PAR product. In: Algorithm Updates for the Fourth SeaWiFS Data Reprocessing. Hooker, S.B., Firestone, E.R. (eds), NASA/TM-2003-206892, 22: 46-50.

Ganias, K., Somarakis,·S., Koutsikopoulos, C., and Machias, A. (2007) Factors affecting the spawning period of sardine in two highly oligotrophic Seas. Mar. Biol. 151: 1559-1569.

Giannoulaki, M., Machias, A., Valavanis, V., Somarakis, S., Palialexis, A., Tsagarakis, K., and Papaconstantinou, C. (2007) Spatial modeling of the European sardine habitat in the Eastern Mediterranean basin using GAMs and GIS tools. Proceedings of the $38^{\text {th }}$ CIESM Congress, April 2007, Turkey: Istanbul, pp. 486.

Giannoulaki, M., Valavanis, V.D., Palialexis, A., Tsagarakis, K., Machias, A., Somarakis, S., and Papaconstantinou, C. (2008) Modelling the presence of 
anchovy Engraulis encrasicolus in the Aegean Sea during early summer, based on satellite environmental data. Hydrobiologia 612: 225-240.

Giannoulaki, M., Somarakis, S., Machias, A., Kalianiotis, A., and Papaconstantinou, C. (2009) Stock assessment of anchovy and sardine in GSA 22 (2000-2006) applying Integrated Catch at Age analysis. General fisheries commission for the Mediterranean scientific advisory committee, Sub-Committee for Stock Assessment, Working Group on Small Pelagic Species, Ancona, 25-30 October 2009

Giannoulaki, M., Iglesias, M., Tugores Ferra, P., Bonnano, A., Quinci, E., De Felice, A., Gramolini, R., Liorzou, B., Tičina, V., Pyrounaki, M.M., Tsagarakis, K., Machias, A., Somarakis, S., Schismenou, E., Basilone, W., Leonori, I., Patti, B., Miguel, J., Oñate, D., Roos, D., Bigot, J.L., and Valavanis V. (2010) Identifying the potential habitat of anchovy Engraulis encrasicolus during different life stages in the Mediterranean Sea. ICES C.M. 2010/R:10

Giráldez, A., Torres, P., Quintanilla, L., and Baro, J. (2005) Anchovy (Engraulis encrasicolus) and sardine (Sardina pilchardus) Stock Assessment in the GFCM Geographical Sub-Area 01 (Northern Alboran Sea) and 06 (Northern Spain).Working Document, GFCM, SCSA, Working Group on Small Pelagic.

Guisan, A., and Zimmermann, N.E. (2000) Predictive habitat distribution models in ecology. Ecol. Model. 135: 147-186.

Guisande, C., Vergara, A.R., Riveiro, I., and Cabanas, J.M. (2004) Climate change and abundance of the Atlantic-Iberian sardine (Sardina pilchardus). Fish. Oceanogr. 13(Suppl. 2): 91-101.

Hanley, J.A., and McNeil, B.J. (1982) The meaning and use of the area under a Receiver Operating Characteristic (ROC) curve. Radiology 143: 29-36. 
Hastie, T., and Tibshirani, R. (1990) Generalized Additive Models. London: Chapman and Hall, 335pp.

Hilborn, R., and Mangel, M. (1997) The Ecological Detective. Confronting Models with data. Monographs in Populations Biology 28, Princeton: Princeton University Press, 315pp.

Isari, S., Ramfos, A., Somarakis, S., Koutsikopoulos, C., Kallianiotis, A., and Fragopoulou, N. (2006) Mesozooplankton distribution in relation to hydrology of the Northeastern Aegean Sea, Eastern Mediterranean. J. Plankton Res. 28: 241255.

Jiménez-Valverde, A., and Lobo, J.M. (2006) The ghost of unbalanced species distribution data in geographical model predictions. Diversity Distrib. 12: 521524.

Jiménez-Valverde, A., Lobo, J.M., and Hortal, J. (2008) Not as good as they seem: the importance of concepts in species distribution modelling. Diversity Distrib. 14(suppl. 6): 885-890.

Katsanevakis, S., Maravelias, C.D., Damalas, D., Karageorgis, A.P, Tsitsika, E.V., Anagnostou C., and Papaconstantinou C. (2009) Spatiotemporal distribution and habitat use of commercial demersal species in the eastern Mediterranean Sea. Fish. Oceanogr. 18(Suppl. 6): 439-457.

Kirk, J.T.O., (1996) Light and photosynthesis in aquatic ecosystems. New York: Cambridge University Press, 509 pp.

Larnicol, G., Ayoub, N., and Le Traon, P.Y. (2002) Major changes in Mediterranean Sea level variability from 7 years of TOPEX/Poseidon and ERS-1/2 data. J. Mar. Syst. 33: 63-89. 
Lejeusne, C., Chevaldonne, P., Pergent-Martini, C., Boudouresque, C.F., and Perez, T. (2010) Climate change effects on a miniature ocean: the highly diverse, highly impacted Mediterranean Sea. Tr. Ecol. Evol. 25(Suppl. 4): 250-260.

Leonori, I., Azzali, M., and De Felice, A. (2007a) Assessment of small pelagic fish by acoustic methods in south western Adriatic Sea. Working Document, GFCM SCSA, Working Group on the Small Pelagic, Athens 13-14 September 2007.

Leonori, I., Azzali, M., and De Felice, A. (2007b) Assessment of small pelagic fish by acoustic methods in north western Adriatic Sea. Working Document, GFCM SCSA, Working Group on the Small Pelagic, Athens 13-14 September 2007.

Leonori, I., Azzali, M., De Felice, A., Parmiggiani, F., Marini, M., Grilli, F., and Gramolini, R. (2009) Small pelagic fish biomass in relation to environmental parameters in the Adriatic Sea. Proceedings of the Joint AIOL-SItE Meeting, 1720 September 2007, Ancona. Available online at: http://www.ecologia.it/ congressi/XVII/articles/, 213-217

Leonori, I., De Felice, A., Campanella, F. and Biagiotti, I. (2010) Stock Assessment form of Sardina pilchardus in the Southern Adriatic Sea (GSA18). Working paper, GFCM, SCSA, Working Group on the Small Pelagic. General fisheries commission for the Mediterranean scientific advisory committee, Sub-Committee for Stock Assessment, Working Group on Small Pelagic Species, Mazara del Vallo, (Italy), 1- 6 November 2010

Lloret, J., Lleonart, J., Solea, I., and Fromentin, J.M. (2001) Fluctuations of landings and environmental conditions in the north-western Mediterranean Sea. Fish. Oceanogr. 10(Suppl. 1): 33-50. 
Lobo, J.M., Jimenez-Valverde, A., and Real, R. (2008) AUC: a misleading measure of the performance of predictive distribution models. Global Ecol. Biogeogr. 17(Suppl. 2): 145-151.

Millot, C. (1990) The Gulf of Lions' hydrodynamics. Cont. Shelf Res. 10(Suppl. 911): 885-894.

Morello, E.B., and Arneri, E. (2009) Anchovy and sardine in the Adriatic Sea - An Ecological Review. Oceanogr. Mar. Biol. Annu. Rev. 47:209-256.

Pauly, D., Christensen, V., and Walters, C. (2000) Ecopath, Ecosim, and Ecospace as tools for evaluating ecosystem impact of fisheries. ICES J. mar. Sci. 57: 697-706.

Petitgas, P., Massé, J., Beillois, P., Lebarbier, E., and Le Cann, A. (2003) Sampling variance of species identification in fisheries-acoustic surveys based on automated procedures associating acoustic images and trawl hauls. ICES J. Mar. Sci. 60: 437-445.

Planque, B., Bellier, E., and Lazure, P. (2007) Modelling potential spawning habitat of sardine (Sardina pilchardus) and anchovy (Engraulis encrasicolus) in the Bay of Biscay. Fish. Oceanogr. 16: 16-30.

Pujol, M.I., and Larnicol, G. (2005) Mediterranean Sea eddy kinetic energy variability from 11 years of altimetric data. J. Mar. Syst. 58: 121-142.

R Development Core Team (2008) R: A language and environment for statistical computing. R Foundation for Statistical Computing, Vienna. Available online at: www.R-project.org

Ramzi, A., Hbid, My.,L., and Ettahiri, O. (2006) Larval dynamics and recruitment modelling of the Moroccan Atlantic coast sardine (Sardina pilchardus). Ecol. Model. 197: 296-302. 
Sacau, M., Pierce, G.J., Wang, J., Arkhipkin, A.I., Portela, J., Brickle, P., Santos, M.B., Zuur, A.F., and Cardoso, X. (2005) The spatio-temporal pattern of Argentine shortfin squid Illex argentinus abundance in the southwest Atlantic. Aq. Living Res. 18: 361-372.

Segurado, P., Araújo, M.B., and Kunin, W.E. (2006) Consequences of spatial autocorrelation for niche-based models. J. Appl. Ecol. 43(suppl. 3): 433-444.

Simmonds, J., and MacLennan, D. (2005) Fisheries acoustics, theory and practice. 2nd ed. Oxford: Blackwell Publishing, 437pp.

Smith, W.H.F., and Sandwell, D.T. (1997) Global sea floor topography from satellite altimetry and ship depth soundings. Science 277: 1956-1962.

Somarakis, S., Drakopoulos, P., and Filippou, V. (2002) Distribution and abundance of larval fishes in the northern Aegean Sea-eastern Mediterranean- in relation to early summer oceanographic conditions. J. Plankton Res. 24: 339-357.

Somarakis, S., Tsianis, D.E., Machias, A., and Stergiou, K.I. (2006) An overview of biological data related to anchovy and sardine stocks in Greek waters. In: Fishes in Databases and Ecosystems. M.L.D. Palomares, K.I. Stergiou and D. Pauly (eds) Fisheries Centre, University of British Columbia: Fisheries Centre Research Reports 14, pp. 56-64.

Somarakis, S., and Nikolioudakis, N. (2007) Oceanographic habitat, growth and mortality of larval anchovy (Engraulis encrasicolus) in the northern Aegean Sea (eastern Mediterranean). Mar. Biol. 152: 1143-1158.

Ticina, V., Katavic, I., Dadic, V., Crubisic, L., Franicevic, M., and Ticina, V.E. (2005) Acoustic estimates of small pelagic fish stocks in the eastern part of the Adriatic Sea: September 2004. Working Document to GFCM, SCSA, Working Group on the Small Pelagic, Rome 26-30 September 2005. 
Tsagarakis, K., Machias, A., Somarakis, S, Giannoulaki, M., Palialexis, A., and Valavanis, V.D. (2008) Habitat discrimination of juvenile sardines in the Aegean Sea using remotely sensed environmental data. Hydrobiologia 612: 215-223.

Tugores Ferra, P., Giannoulaki, M., Iglesias, M., Bonnano, A., Tičina, V., Tsagarakis, K., Machias, A., Patti, B., Leonori, I., De Felice, A., Campanella, F., Díaz, N., Giraldez, A., Valavanis, V., and Papaconstantinou, C. (2010) Habitat suitability modeling for sardine in a highly diverse ecosystem: the Mediterranean Sea. ICES CM: R9, ICES Annual Conference, Nantes, September 2010, France.

Valavanis, V.D., Pierce, G.J., Zuur, A.F., Palialexis, A., Saveliev, A., Katara, I., and Wang, J. (2008) Modelling of Essential Fish Habitat based on Remote Sensing, Spatial Analysis and GIS. Hydrobiologia 612(suppl. 1): 5-20.

Weber, E.D., and McClatchie, S. (2010) Predictive models of northern anchovy Engraulis mordax and Pacific sardine Sardinops sagax spawning habitat in the California Current. Mar. Ecol. Prog. Ser. 406: 251-263.

Wood, S.N., and Augustin, N.H. (2002) GAMs with integrated model selection using penalized regression splines and applications to environmental modelling. Ecol. Model. 157: 157-177.

Wood, S.N. (2006) Generalized Additive Models. An Introduction with R. London: Chapman \& Hall, 392pp.

Zervakis, V., and Georgopoulos, D. (2002) Hydrology and circulation in the Northern Aegean Sea throughout 1997 and 1998. Medit. Mar. Sci. 3: 5-19. 


\section{Tables headings}

Table 1. Environmental satellite parameters and their characteristics. Measurements are extracted from the respective databases on a daily scale and in a next step averaged on a monthly basis.

Table 2. Final GAM models selected. Analysis of deviance for GAM covariates and their interactions of the final model fitted. Level of significance was set to 0.05 . June data refer to North Aegean Sea, July data refer to Gulf of Lions. The (:) sign denotes interaction. Res. d.f= residual degrees of freedom; Res. Deviance=residual deviance; $\mathrm{AIC}=\mathrm{Akaike}$ Information Criterion value; P-value (chi-square) $=$ significance values . SST: Sea Surface Temperature, CHLA: chlorophyll concentration (log transformed), Depth: Bathymetry (cubic root transformed), SLA: Sea Level Anomaly, PAR: Photosynthetic Active Radiation.

Table 3. Mean values of sensitivity and specificity accuracy measures \pm standard error (sterr) for two threshold criteria: MDT (maximize the specificity-sensitivity sum) and prevalence values. The estimated area under the ROC curve (AUC) for each model is also indicated. A: Areas and years included in model selection, B: areas and years not included in model selection. 


\section{Figures legends}

Fig. 1. Map of the study areas where transects of acoustic sampling are shown. Map of water circulation is also shown. Arrows indicate the presence of fronts and gyres (redrawn from Millot, 1990; Somarakis et al., 2002; Artegiani 1997a). LIS: LimnosImvos Steam, NC; Northern Current, Positions and names of the main rivers in the area are also shown. Toponyms mentioned in the text are also indicated.

Fig 2. Abundance (in Biomass in tonnes $/ \mathrm{nm}^{2}$ ) of sardine juveniles in the Gulf of Lions during July 2003, 2004, 2005 and 2008. Sea Level Anomaly distribution (in cm) per respective study year is also shown.

Fig 3. Echo abundance index Nautical Area Scattering Coefficient (NASC in $\mathrm{m}^{2} / \mathrm{nm}^{2}$ ) of sardine juveniles in the N. Aegean Sea during June 2004, 2005, 2006, July 2007 and 2008. Sea Level Anomaly distribution (in cm) per respective study year is also shown.

Fig. 4. Coefficients of the Generalized Additive Models (GAMs) for sardine juveniles against environmental variables for each selected model. CHLA: log transformed Surface chlorophyll concentration (in $\mathrm{mg} \mathrm{m}^{-3}$ ) SST: Sea Surface Temperature $\left({ }^{\circ} \mathrm{C}\right)$, SLA: Sea Level Anomaly (in cm), Depth: Cube root transformed Bottom Depth (in m), PAR: Photosynthetically Active Radiation (in Einstein $\mathrm{m}^{-2}$ day $^{-1}$ ). The interaction plots are also shown. Black thick lines indicate the value of GAMs coefficient, dotted lines represent the confidence intervals at $\mathrm{p}=0.05$. The rug under the single variable effects plots indicates the density of points for different variable values. 
Fig 5. Annual habitat suitability maps indicating the probability for sardine juvenile presence in the Gulf of Lions, based on GAM model from July in the same area. GIS resolution for mean monthly satellite values used for prediction was $4 \mathrm{~km}$. Scale indicates probability range.

Fig 6. Annual habitat suitability maps indicating the probability for sardine juvenile presence in the N. Aegean Sea, based on GAM model from June in the same area. GIS resolution for mean monthly satellite values used for prediction was $4 \mathrm{~km}$. Scale indicates probability range.

Fig. 7. (A) Mean probability, (B) persistence index and (C) allocation maps concerning habitat suitability for the presence of sardine juveniles in the Mediterranean Sea for June. GIS resolution for mean monthly satellite values used was 4 km concerning June 2004 to 2008. Numbers indicate toponyms mentioned in the text. 1. Alboran Sea, 2. Sicily Strait, 3. Gabes Gulf, 4. Nile Delta, 5. Levantine basin, 6. Cretan Sea, 7. Aegean Sea, 8. Tyrrhenian Sea, 9. Island of Sardinia, 10. Ligurian Sea, 11. Catalan Sea, 12. Gulf of Lions, 13. Adriatic Sea, 14. Dalmatian islands.

Fig 8. (A) Mean probability, (B) persistence index and (C) allocation maps concerning habitat suitability for the presence of sardine juveniles in the Mediterranean Sea for July. GIS resolution for mean monthly satellite values used was $4 \mathrm{~km}$ concerning July 2004 to 2008. Numbers indicate toponyms mentioned in the text. 1. Alboran Sea, 2. Sicily Strait, 3. Gabes Gulf, 4. Nile Delta, 5. Levantine basin, 6. Cretan Sea, 7. Aegean Sea, 8. Tyrrhenian Sea, 9. Island of Sardinia, 10. 
Ligurian Sea, 11. Catalan Sea, 12. Gulf of Lions, 13. Adriatic Sea, 14. Dalmatian islands.

Fig. 9. Graph presents the relationship between the standardized sardine juveniles abundance and the standardized extent of "hot spot areas" (i.e., potential habitat area A075) concerning the Gulf of Lions, Adriatic Sea and N. Aegean Sea. Standardized Abundance: Abundance estimates of sardine juveniles expressed as \% difference from the mean values per region, Standardized A075: extent of area A075 expressed as \% difference from the mean values per region. 
Table 1.

\section{PARAMETER ABBREVIATION SENSOR/MODEL RESOLUTION $\quad$ SOURCE}

Sea Surface

Chlorophyll-a

Sea Surface

Temperature

Photosynthetically

PAR

Active Radiation

Sea Level

Anomaly

Sea Surface

Salinity
SLA

Merged Jason-1,

Envisat, ERS-2,

GFO, T/P

SSS

NOAA NCEP

EMC CMB

GODAS model
SeaWiFS

$9 \mathrm{~km}$

oceancolor.gsfc.nasa.gov

$4 \mathrm{~km}$

oceancolor.gsfc.nasa.gov

$1.5 \mathrm{~km}$

eoweb.dlr.de:8080

AVHRR

$0.25^{\circ}$ (interpolated to

www.jason.oceanobs.com

$$
1.5 \mathrm{~km} \text { using }
$$

ArcInfo’s topogrid)

$0.5^{\circ}$ (interpolated to iridl.ldeo.columbia.edu

$$
1.5 \mathrm{~km} \text { using }
$$

ArcInfo’s topogrid) 
Table 2.

\begin{tabular}{|c|c|c|c|c|c|c|c|}
\hline & & & Residual & Residual & Deviance & & \\
\hline & & Parameters & Df & Deviance & explained & AIC & P-value \\
\hline $\begin{array}{l}\text { Pooled } \\
\text { model }\end{array}$ & June + July & $\begin{array}{l}\text { s(Depth, SLA })+s(\text { SST })+ \\
s(\text { CHLA })+\text { as.factor(Month) }\end{array}$ & 1796.25 & 1202.39 & $48.4 \%$ & 1275.89 & $<<0.000$ \\
\hline \multirow[t]{2}{*}{$\begin{array}{l}\text { Monthly } \\
\text { models }\end{array}$} & July & $s($ Depth, SST $)+s($ SLA $)+s($ CHLA $)$ & 1297.85 & 1007.63 & $45.1 \%$ & 1081.92 & $<<0.000$ \\
\hline & June & s(Depth,PAR)+s(SLA)+s(CHLA) & 433.15 & 137.91 & $51.1 \%$ & 201.61 & $<<0.000$ \\
\hline
\end{tabular}


Table 3.

\begin{tabular}{lcccccc}
\hline \multirow{2}{*}{ Model } & & MDT & MDT & Prevalence & Prevalence & \\
& Areas & Sensitivity & Specificity & Sensitivity & Specificity & AUC \\
\hline June & A & $0.90 \pm 0.02$ & $0.77 \pm 0.05$ & $0.62 \pm 0.01$ & $0.96 \pm 0.01$ & $0.91 \pm 0.027$ \\
& B & $0.82 \pm 0.08$ & $0.71 \pm 0.17$ & $0.52 \pm 0.12$ & $0.86 \pm 0.04$ & $0.75 \pm 0.08$ \\
July & A & $0.83 \pm 0.04$ & $0.84 \pm 0.04$ & $0.82 \pm 0.01$ & $0.77 \pm 0.08$ & $0.90 \pm 0.03$ \\
& B & $0.49 \pm 0.16$ & $0.88 \pm 0.06$ & $0.38 \pm 0.12$ & $0.86 \pm 0.03$ & $0.77 \pm 0.05$ \\
Pooled July \& June & A & $0.78 \pm 0.05$ & $0.79 \pm 0.04$ & $0.56 \pm 0.08$ & $0.86 \pm 0.04$ & $0.82 \pm 0.03$ \\
& B & $0.53 \pm 0.19$ & $0.88 \pm 0.06$ & $0.44 \pm 0.13$ & $0.87 \pm 0.02$ & $0.77 \pm 0.06$ \\
\hline
\end{tabular}



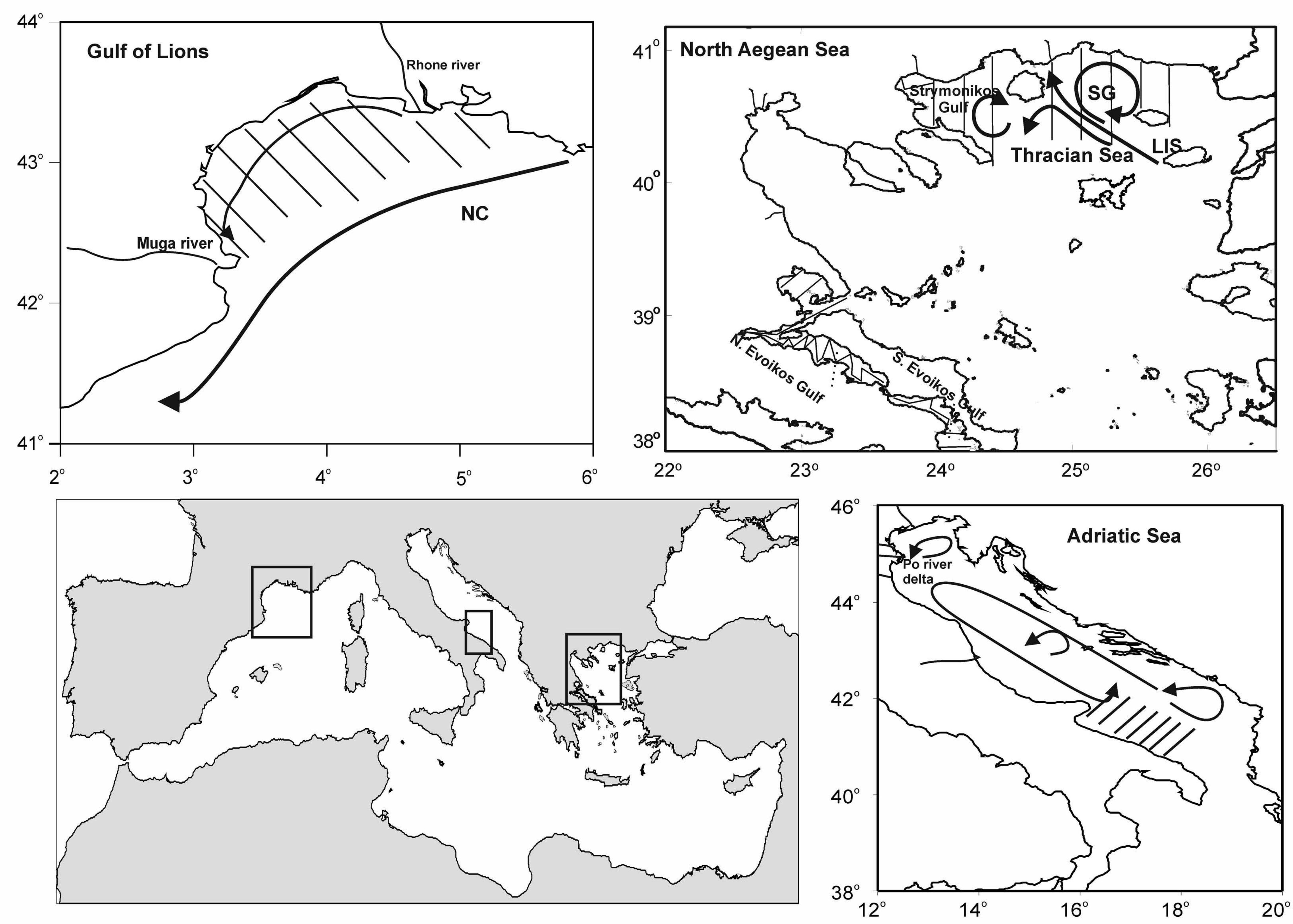

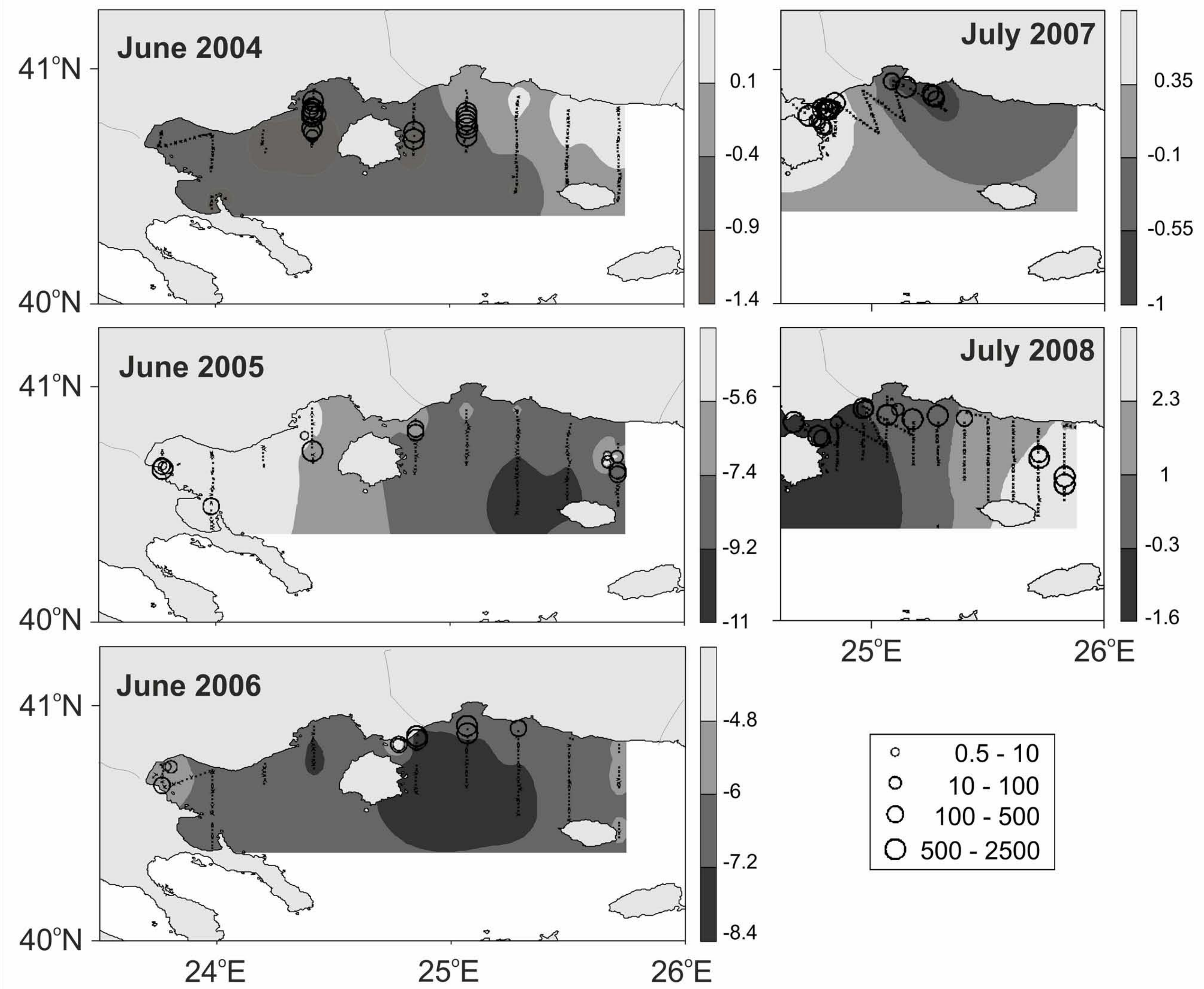

\begin{tabular}{|rr|}
\hline$\circ$ & $0.5-10$ \\
0 & $10-100$ \\
0 & $100-500$ \\
\hline & $500-2500$ \\
\hline
\end{tabular}




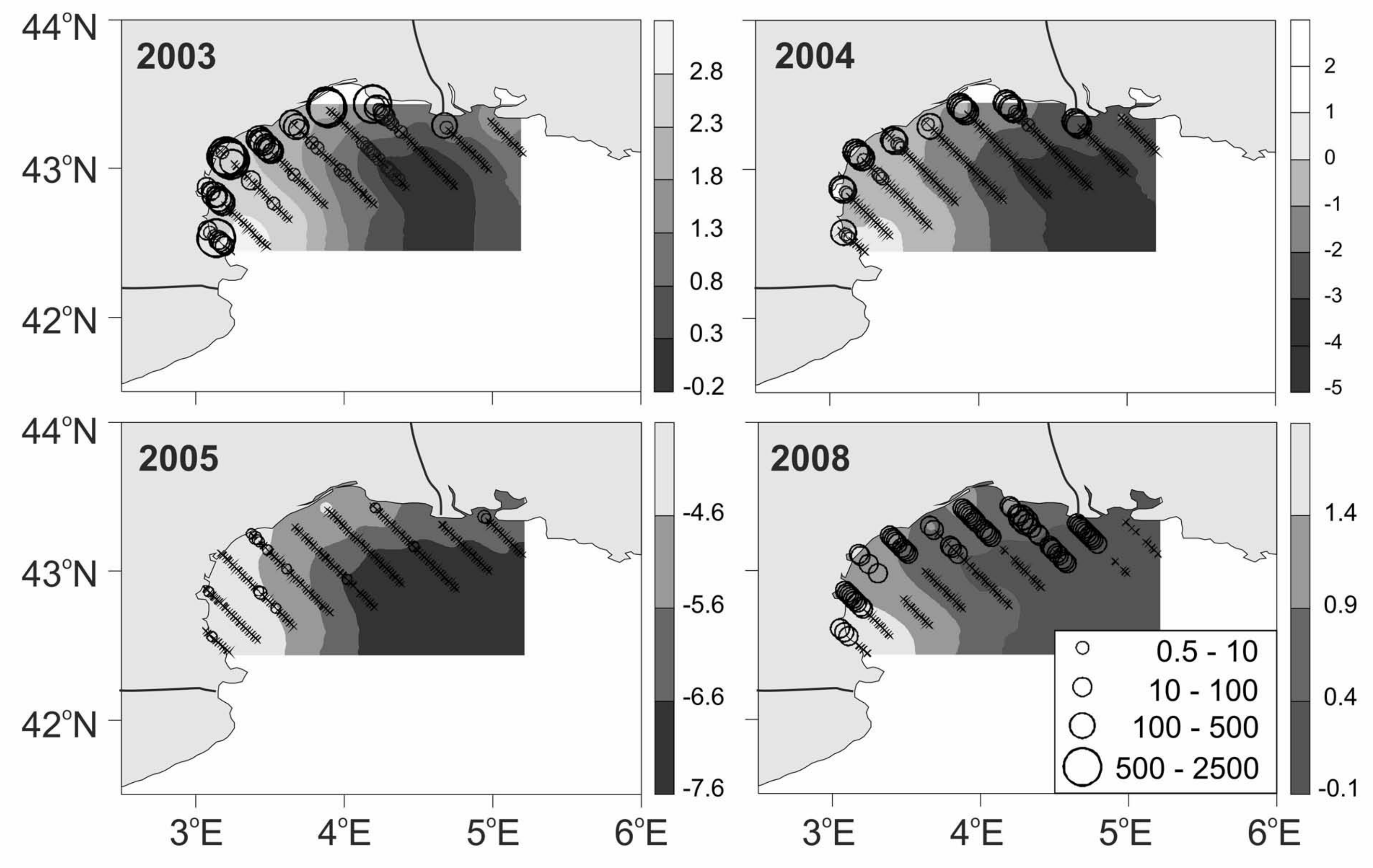


Pooled model Gulf of Lions +

N. Aegean Sea (June+ July)
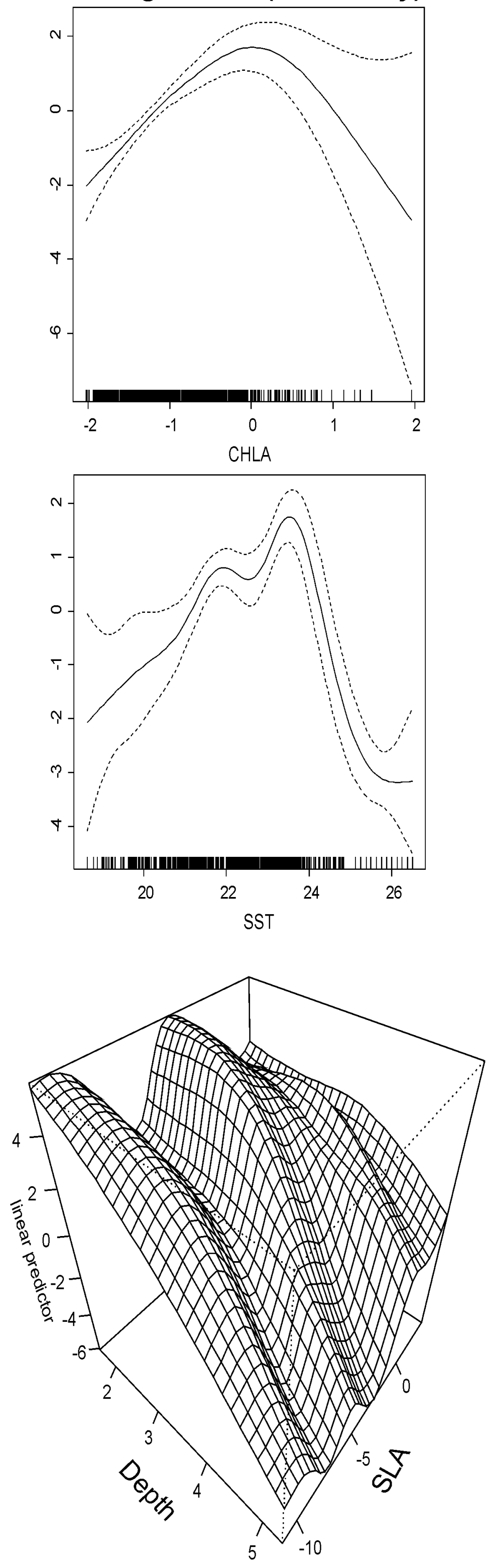

\section{Gulf of Lions model ( July)}
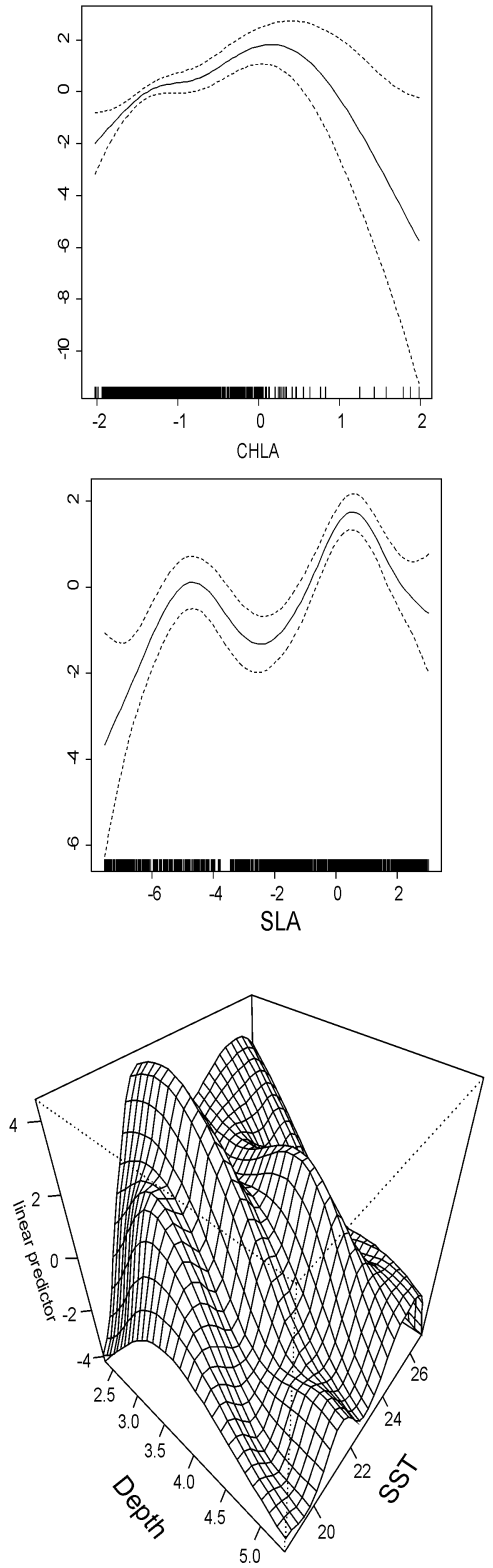

N. Aegean Sea model (June)
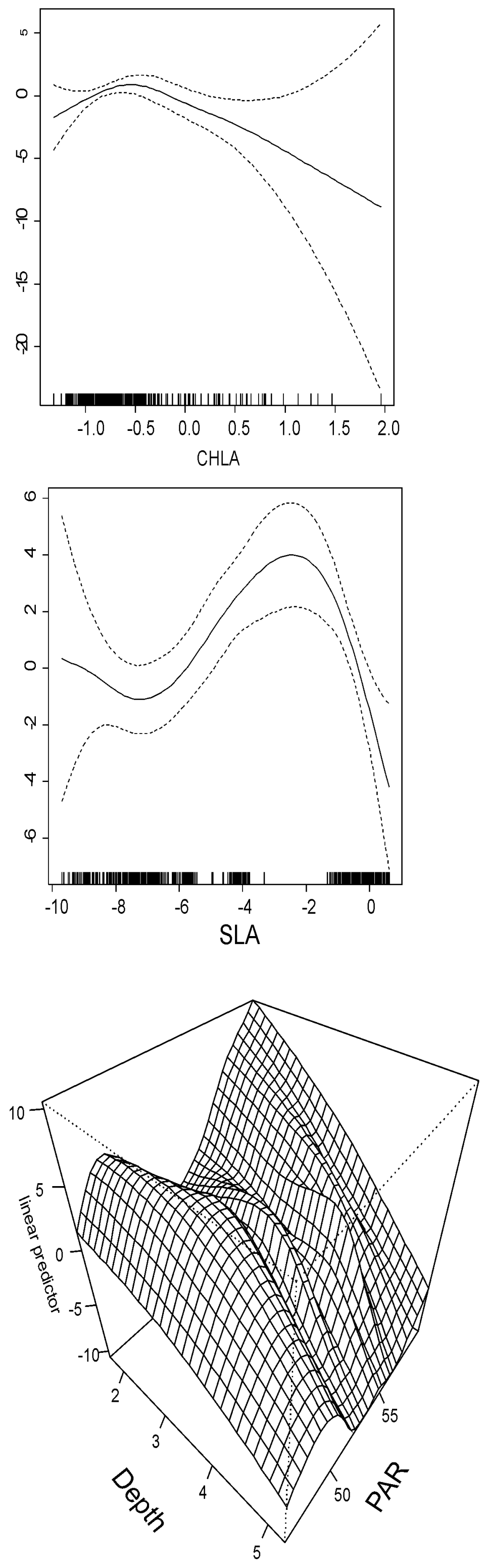

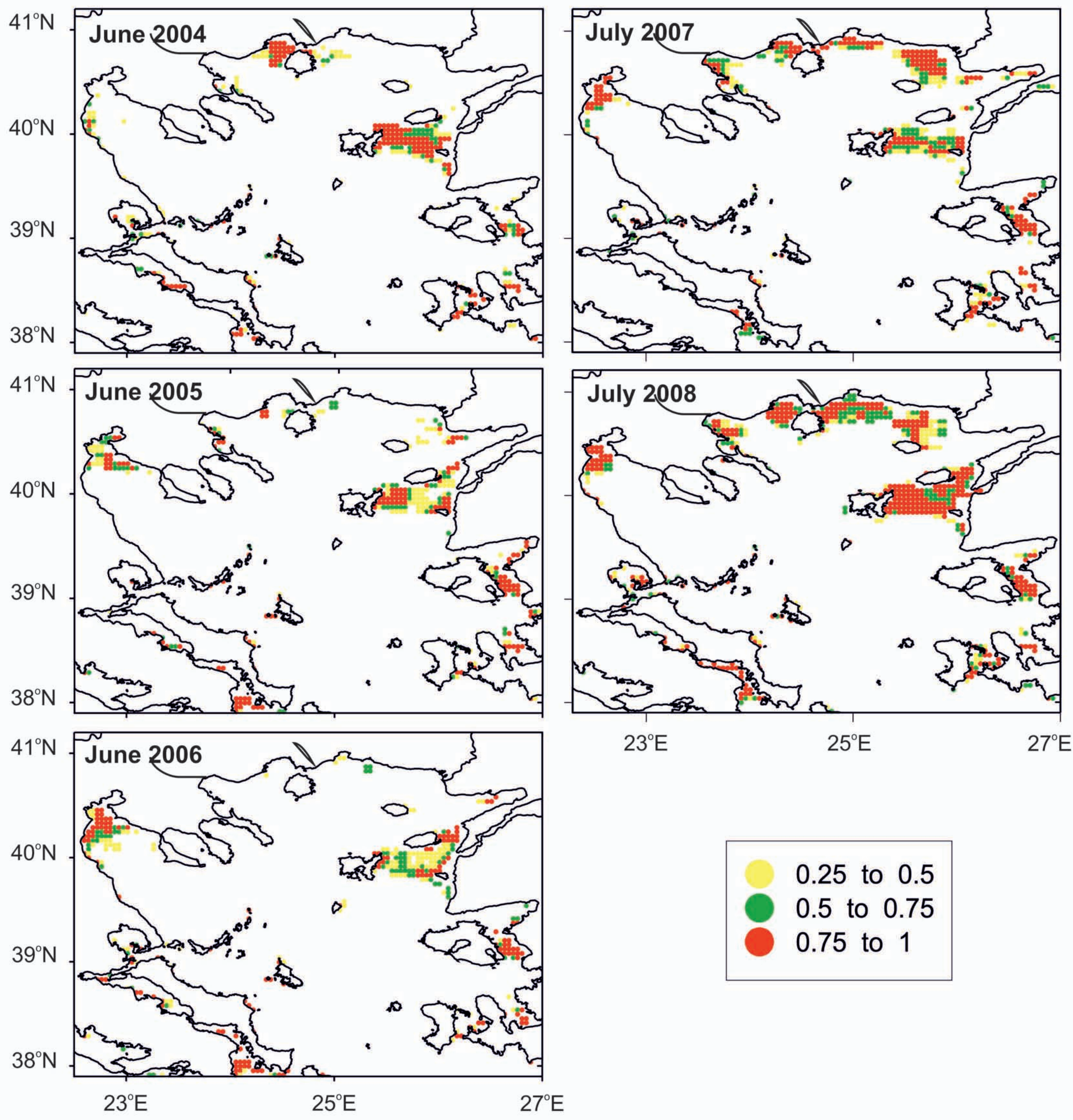

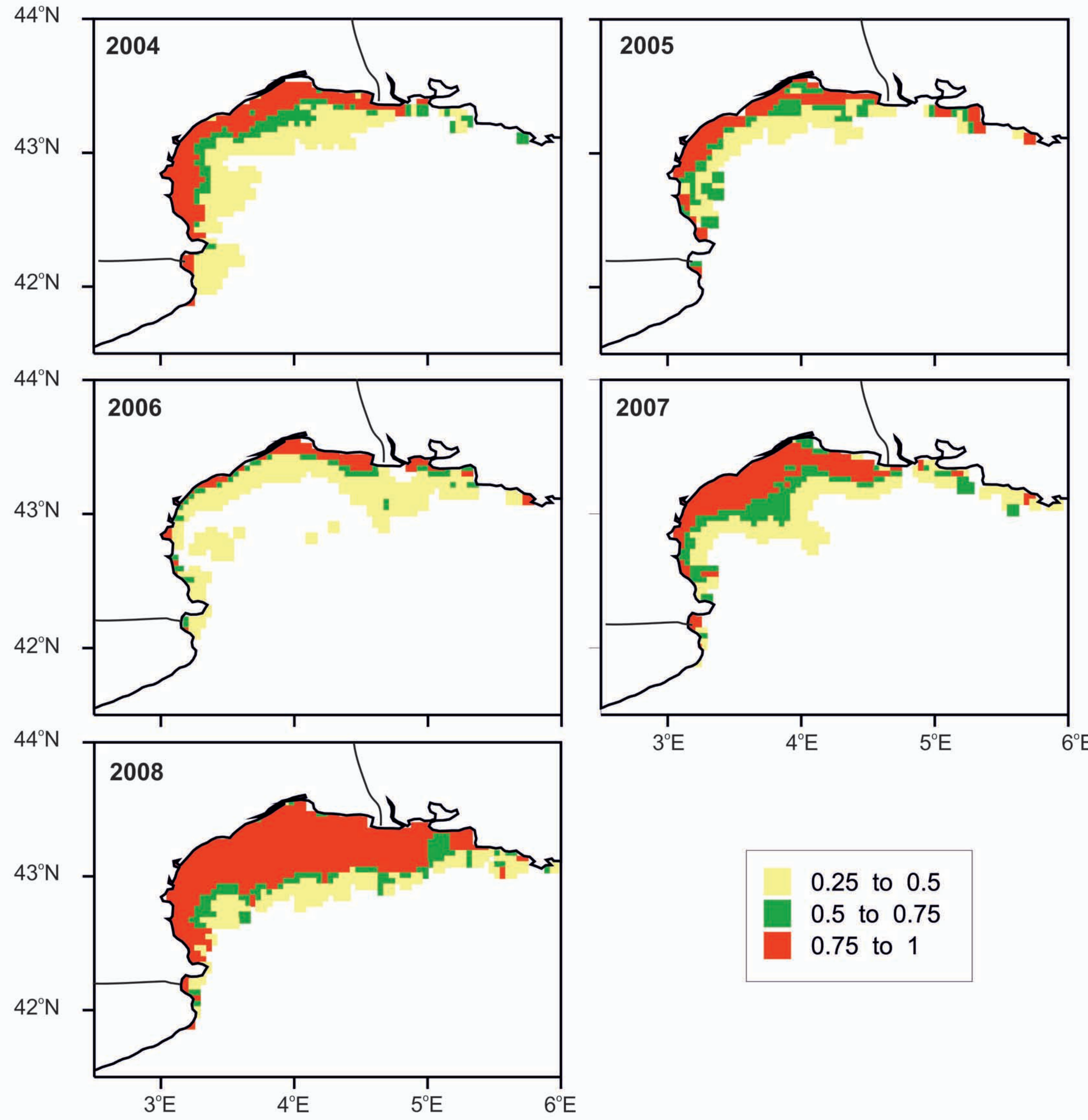
0.25 to 0.5
0.5 to 0.75
0.75 to 1 


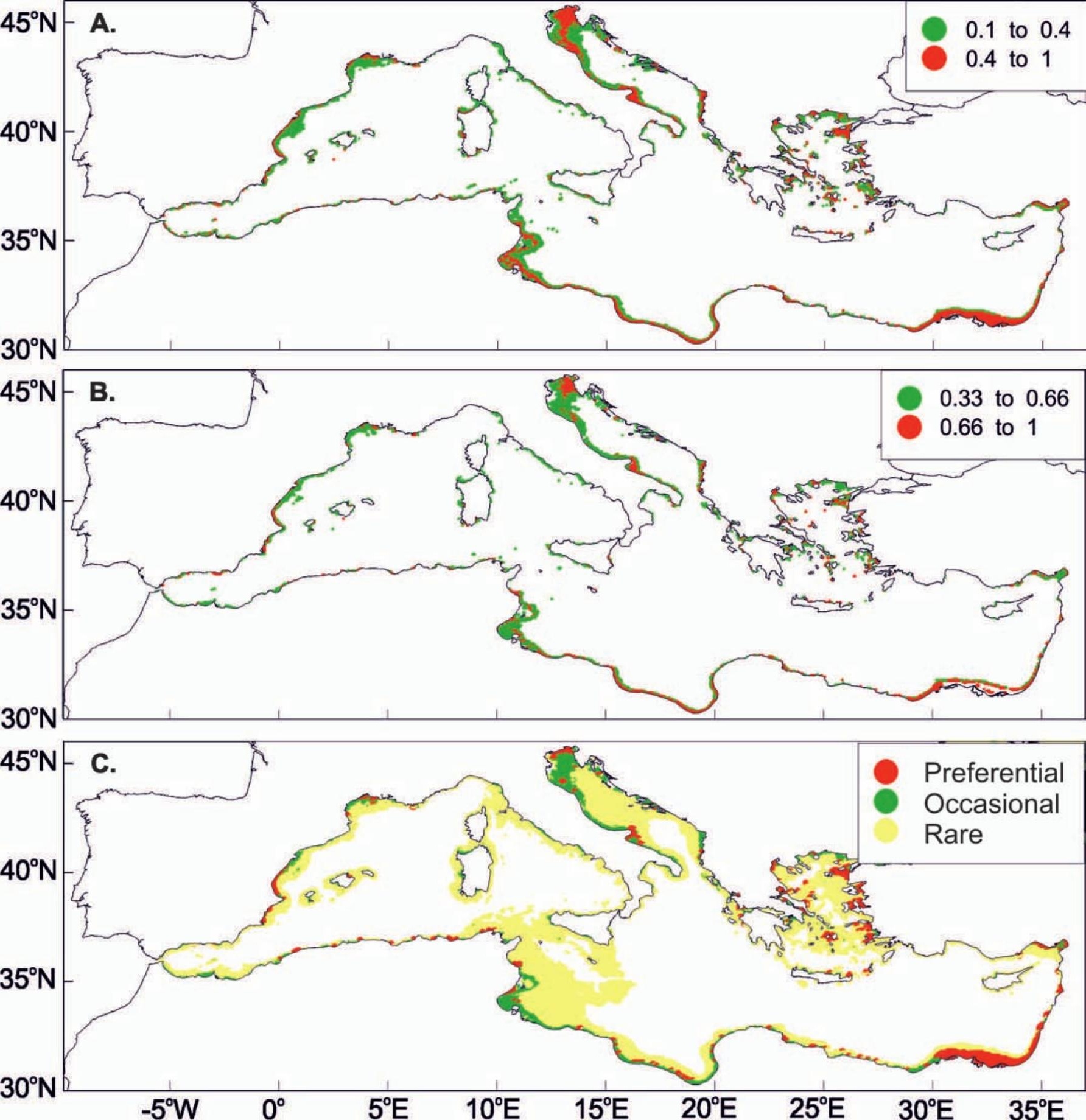




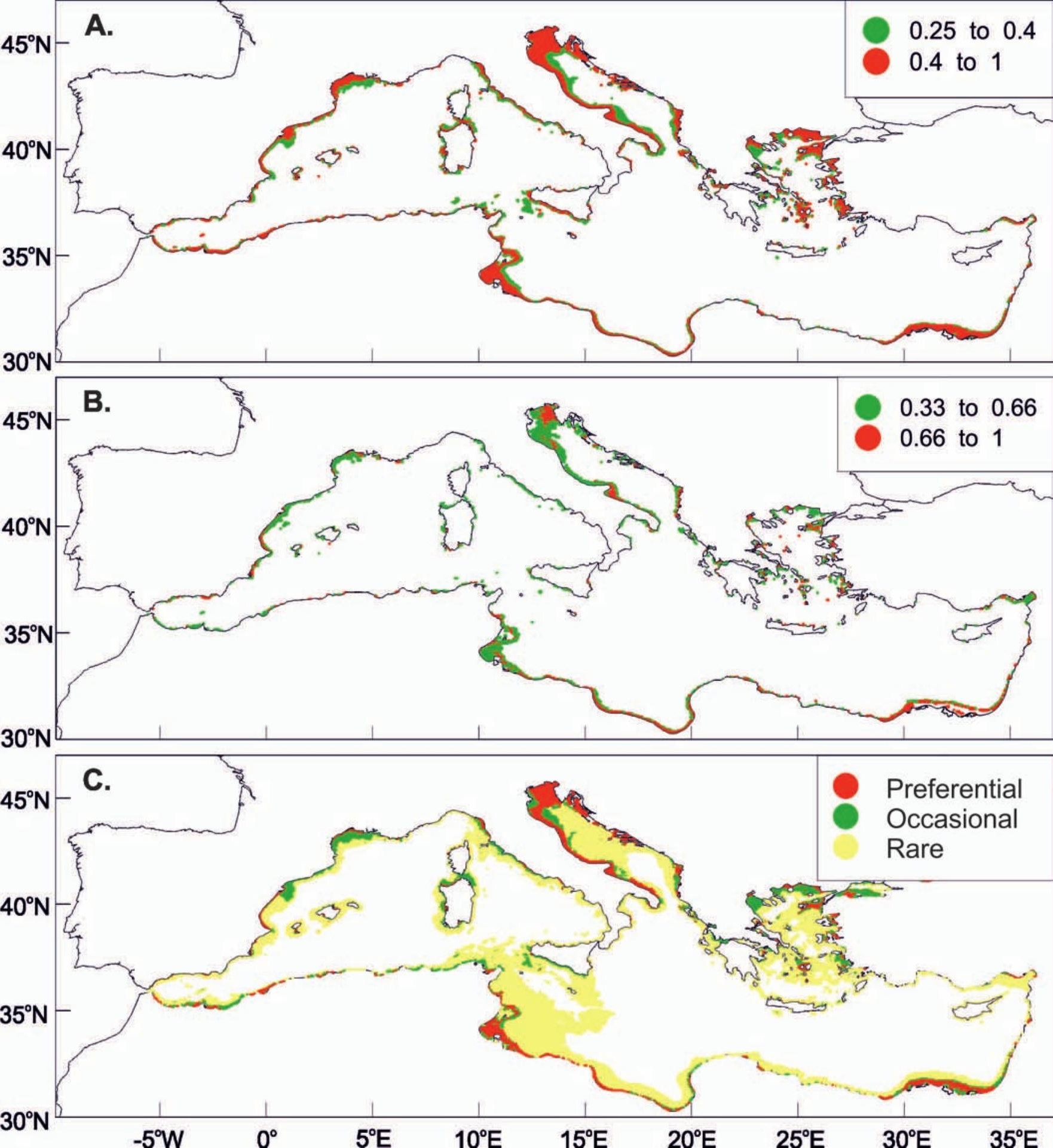




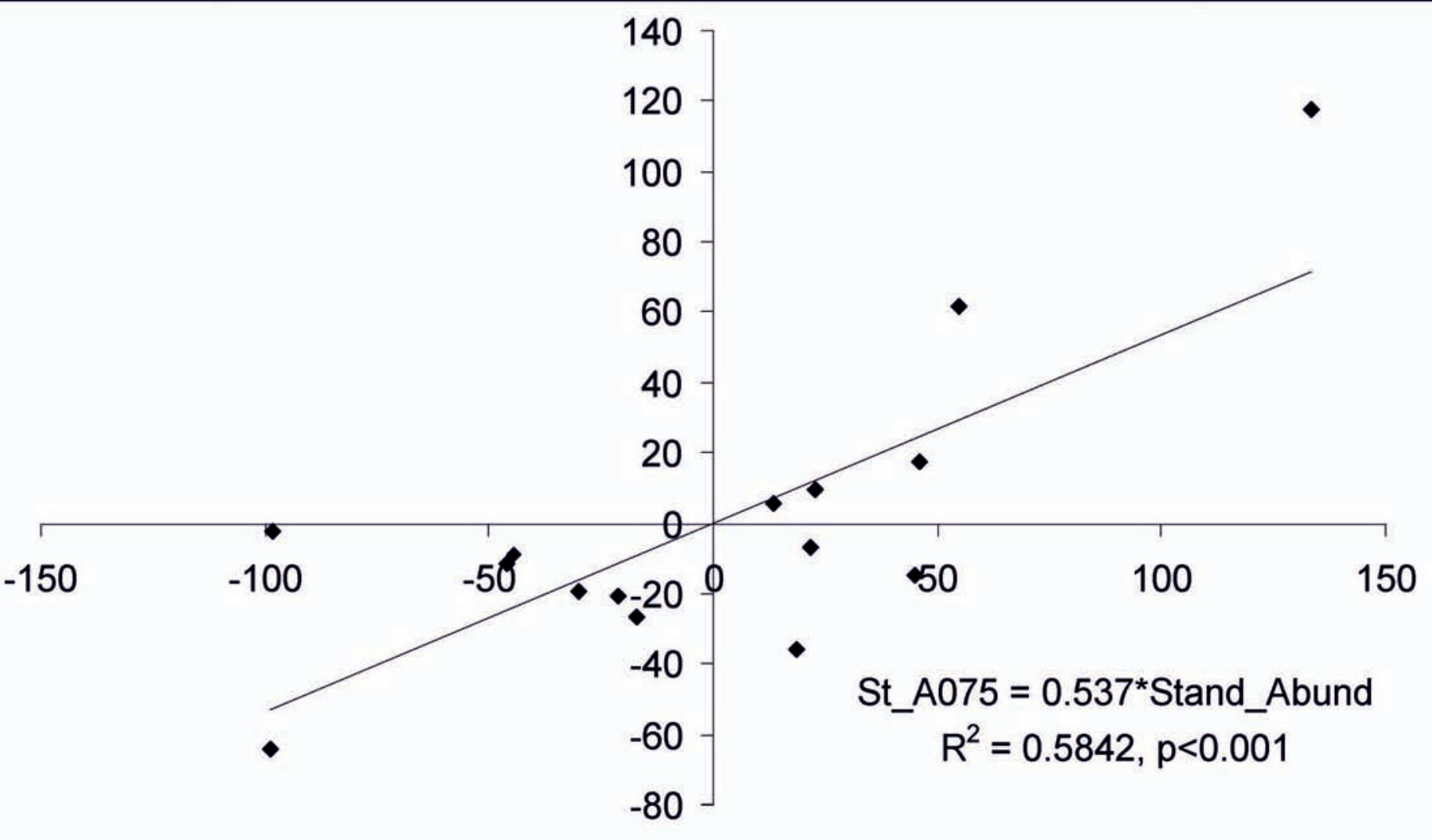

